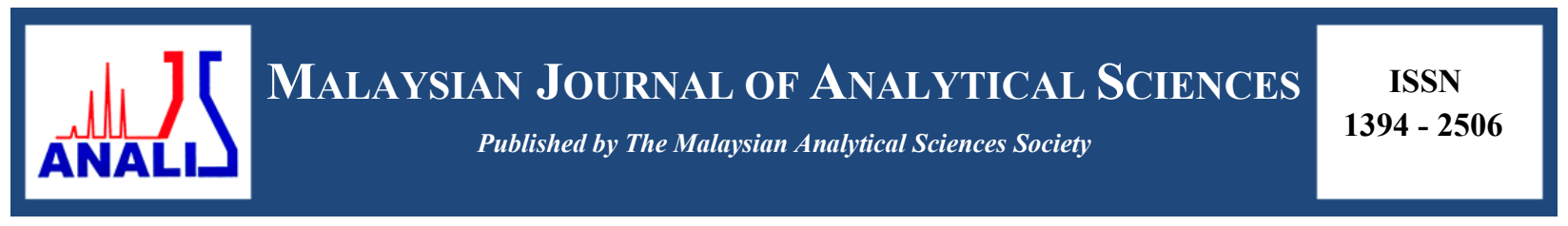

\title{
SURFACE MODIFICATION OF PSF/TIO 2 MEMBRANES USING SILANE COUPLING AGENTS AND DC PLASMA TECHNIQUE
}

\section{(Modifikasi Permukaan Membran PSF/TiO 2 Menggunakan Ejen Gandingan Silana dan Teknik Plasma DC)}

\author{
Soraya Ruangdit ${ }^{1}$, Thawat Chittrakarn ${ }^{1}$, Sudkhet Anuchit ${ }^{1}$, Yutthana Tirawanichakul ${ }^{1}$, Chalad Yuenyao ${ }^{2}$ \\ ${ }^{I}$ Membrane Science and Technology Research Center, Department of Physics, Faculty of Science, \\ Prince of Songkla University, Hat Yai, Songkhla 90112, Thailand \\ ${ }^{2}$ Department of Physics, Faculty of Science and Technology, \\ Phetchabun Rajabhat University, 83 M.11 St.Saraburi-Lom Sak, Muang, Phetchabun 67000, Thailand \\ *Corresponding author: tawat.c@psu.ac.th
}

Received: 26 August 2016; Accepted: 8 January 2017

\begin{abstract}
Preparation and surface modification of $\mathrm{PSF} / \mathrm{TiO}_{2}$ membranes by DC Ar-plasma were conducted to improve membrane hydrophilicity and gas permeation efficiency. Using $\mathrm{TiO}_{2}$ as a photocatalyst, photocatalysis could be induced upon the plasma exposure. Radicals from this process led to an increase in the membrane hydrophilicity. In order to improve the dispersion quality of $\mathrm{TiO}_{2}$ in an organic membrane, methyltrimethoxysilane (TMMS) or ethyltrimethoxysilane (TEMS) was utilized as coupling agents to modify the $\mathrm{TiO}_{2}$ surface prior to blending. The coupling agents caused organic silane bonds on the TiO${ }_{2}$ surface leading to a better dispersion of nanoparticle on the membrane matrix. The incorporation of modified- $\mathrm{TiO}_{2}$ tended to decrease membrane water contact angles (WCA) to the lowest value when compared with PSF membranes with unmodified $\mathrm{TiO}_{2}$ and neat PSF membranes. Results also showed that TMMS could produce better outcomes compared to TEMS. It was found that the modified- $\mathrm{TiO}_{2}$ could decrease the WCA. More importantly, pressure normalized flux of $\mathrm{CO}_{2}$ and $\mathrm{CH}_{4}$ gases of $\mathrm{PSF} /$ modified- $\mathrm{TiO}_{2}$ membrane was found to increase with slightly decrease in the selectivity of $\mathrm{CO}_{2} / \mathrm{CH}_{4}$.
\end{abstract}

Keywords: silane coupling agent, surface modification, gas separation membrane, low pressure DC-plasma, polysulfone

\begin{abstract}
Abstrak
Penyediaan dan modifikasi permukaan membran $\mathrm{PSF} / \mathrm{TiO}_{2}$ oleh $\mathrm{DC}$ Ar-plasma telah dijalankan untuk meningkatkan kehidrofilikan membran dan kecekapan penyerapan gas. Menggunakan $\mathrm{TiO}_{2}$ sebagai foto-pemangkin, fotopemangkinan dapat didorong apabila terdedah kepada plasma. Radikal daripada proses ini membawa kepada peningkatan dalam kehidrofilikan membran. Untuk meningkatkan kualiti penyebaran $\mathrm{TiO}_{2}$ dalam membran organik, metiltrimetoksisilana (TMMS) atau etiltrimetoksisilana (TEMS) telah digunakan sebagai agen gandingan untuk mengubah suai permukaan $\mathrm{TiO}_{2}$ sebelum campuran. Ejen-ejen gandingan menyebabkan ikatan silana organik di permukaan $\mathrm{TiO}_{2}$ yang membawa kepada penyebaran nanopartikel yang lebih baik pada matriks membran. Penggabungan $\mathrm{TiO}_{2}$ yang diubahsuai cenderung untuk mengurangkan sudut sentuhan air membran (WCA) kepada nilai yang paling rendah berbanding membran PSF dengan $\mathrm{TiO}_{2}$ yang tidak diubahsuai dan membran PSF kawalan. Keputusan juga menunjukkan bahawa TMMS boleh menghasilkan hasil yang lebih baik berbanding PPSMI. Ia telah mendapati bahawa $\mathrm{TiO}_{2}$ yang diubahsuai boleh mengurangkan WCA. Lebih penting lagi, tekanan fluks normal gas $\mathrm{CO}_{2}$ dan $\mathrm{CH}_{4}$ daripada membran $\mathrm{PSF} / \mathrm{TiO}_{2}$ yang diubahsuai didapati meningkat dengan sedikit penurunan kepilihan $\mathrm{CO}_{2} / \mathrm{CH}_{4}$.
\end{abstract}

Kata kunci: ejen gandingan silana, modifikasi permukaan, membran pemisahan gas, tekanan rendah dc-plasma, polisulfon 


\section{Ruangdit et al: SURFACE MODIFICATION OF PSF/TIO ${ }_{2}$ MEMBRANES USING SILANE COUPLING \\ AGENTS AND DC PLASMA TECHNIQUE}

\section{Introduction}

Membrane technology is currently widely used in many industrial sectors and one of its important applications is for gas separation process. As $\mathrm{CO}_{2}$ gas is the main causes of greenhouse effect that leads to global warming, many attempts were made to develop an ideal membrane for $\mathrm{CO}_{2}$ adsorption and separation [1]. Polysulfone (PSF) is one of the high potential and widely used polymers because it has many advantages such as excellent stability and resistivity to high temperature and acid-base environments and easy to be used for membrane making [2,3]. However, PSF is hydrophobic in nature [4]. For the PSF membranes to be used in the $\mathrm{CO}_{2} / \mathrm{CH}_{4}$ gas separation, the hydrophilicity of the membrane surface needs to be improved. This improvement is quite important due to the differences of the quadrupole moments of these two gases [5].

Konruang et al. [5] discussed differences of several gases that have small molecules and very little differences in size. Besides, electronic properties, polarizability and quadrupole moment, which we can be used for the extract gas, were also discussed. Table 1 shows the structure, polarizability and quadrupole moment of $\mathrm{CO}_{2}$ and $\mathrm{CH}_{4}$ gases [6]. Considering electronic properties of $\mathrm{CO}_{2}$ and $\mathrm{CH}_{4}$ gases, we can see that membrane surfaces, which have a higher polarity can absorb a higher polarizability and quadrupole moment gas more than of lower polarizability and quadrupole moment gas. Therefore, hydrophilic properties represent the polarity of membrane surfaces, which is the cause for $\mathrm{CO}_{2}$ to permeate more through such a membrane than $\mathrm{CH}_{4}$. The quadrupole moment affects the gas permeation through the membranes. For hydrophilic polymeric membranes, the permeability of $\mathrm{CO}_{2}$, which has a quadrupole moment and polarizability of about $13.4 \times 10^{-40} \mathrm{Cm}^{2}$ and $2.93 \times 10^{-40} \mathrm{~J}^{-1} \mathrm{C}^{2} \mathrm{~m}^{2}$, respectively, is higher than of $\mathrm{CH}_{4}$, which has a quadrupole moment and polarizability of about zero and $2.8910^{-40} \mathrm{~J}^{-1} \mathrm{C}^{2} \mathrm{~m}^{2}$, respectively [6]. Therefore, research and development are required to improve the hydrophilicity of membranes. [5].

Table 1. Structure, physical and electronic properties of gas molecules [6]

\begin{tabular}{llcc}
\hline Molecule & Structure & $\begin{array}{c}\text { Polarizability } \\
\left(10^{-40} \mathbf{J}^{-1} \mathbf{C}^{2} \mathbf{m}^{2}\right)\end{array}$ & $\begin{array}{c}\text { Quadrupole moment } \\
\left(10^{-40} \mathbf{C ~ m}^{2}\right)\end{array}$ \\
\hline $\mathrm{CO}_{2}$ & Linear & 2.93 & 13.4 \\
$\mathrm{CH}_{4}$ & Tetrahedral & 2.89 & 0 \\
\hline
\end{tabular}

Titanium dioxide $\left(\mathrm{TiO}_{2}\right)$ can improve the hydrophilicity of membranes because of its photocatalytic property $[7,8]$. Typically, electrons in the valence band of a photocatalytic material will jump to the conduction band when they are stimulated by a photon. The holes are created in the valence band and the electron from the donor molecule can move to this hole. At the same time, an electron from the valence band can be transferred to the acceptor [9, 10]. For this reason, the photo catalyst can take the interaction with the molecules at the material surface. Additionally, the stimulation of $\mathrm{TiO}_{2}$ at the membrane surface can decrease the surface roughness and eventually, lead to the decrease in membrane contact angle [11].

However, the minimum energy for the stimulation of $\mathrm{TiO}_{2}$ has to be equal with the band energy gap that is about 3.2 $\mathrm{eV}[12,13]$. Unlike PSF, $\mathrm{TiO}_{2}$ is an inorganic material and the dispersion of $\mathrm{TiO}_{2}$ particles in the PSF matrix is quite low. Madaeni et al. [14] studied the increase of $\mathrm{TiO}_{2}$ loading in polyethersulfone (PES) support. Here, an increase in the $\mathrm{TiO}_{2}$ content of the polydimethylsiloxane (PDMS) matrix lead to an increase in the selfcondensation, polarity, and polar groups. Nevertheless, the $\mathrm{CO}_{2}$ permeability in that work is reported to decrease. Chen and Yakovlev [15] studied the modification of $\mathrm{TiO}_{2}$ nanoparticles by the interaction with organic silane. They found the creation of Si-O-Ti bonds and organic groups after $\mathrm{TiO}_{2}$ was modified by 3 -aminopropyltrimethoxysilane (APTES) and phenyltrimethoxysilane (PTMS).

This current work studied the modification of PSF membranes using dry/wet phase inversion method. $\mathrm{TiO}_{2}$ nanoparticles were modified by silane-coupling agents, including trimethoxymethylsilane (TMMS) and triethoxymethylsilane (TEMS). The modified $\mathrm{TiO}_{2}$ was then incorporated into the PSF membrane matrix to increase its hydrophilic properties and the permeance of $\mathrm{CO}_{2}$. In order to further enhance the gas separation properties, the 
obtained membranes were treated by DC Ar-plasma and then the permeance of the hydrophilicity of plasma treated membranes was studied.

Pellets of PSF (UDEL P-1700) were supplied by Solvay (China). Polymer solvents included N,Ndimethylacetamide (DMAc) and tetrahydrofuran (THF) was purchased from Sigma-Aldrich (Singapore) and ACI Lab-scan (Australia), respectively. Titanium dioxide $\left(\mathrm{TiO}_{2} ; 32 \mathrm{~nm}\right.$ APS powder MW. 79.90) nanoparticles, methyltrimethoxysilane (TMMS) and ethyltrimethoxysilane (TEMS) were supplied by Alfa Aesar (China). The TMMS and TEMS were used as silane coupling agent while $\mathrm{TiO}_{2}$ was used as an inorganic additive. Ethanol $(\mathrm{EtOH})$ and methanol $(\mathrm{MeOH})$ were supplied by J.T. Baker. All chemicals and materials were used as received.

In order to modify the surface of $\mathrm{TiO}_{2}$ nanoparticles by a silane coupling agent, $1 \mathrm{~g}$ of $\mathrm{TiO}_{2}$ was dispersed in $100 \mathrm{ml}$ of RO water under vigorous stirring. The obtained solution was sonicated for $10 \mathrm{~min}$ before the addition of the silane coupling agent with a concentration of $12.5 \mathrm{wt} . \%$. The reflux process was taking place for 5 hours at a temperature of $80{ }^{\circ} \mathrm{C}$. The as-modified $\mathrm{TiO}_{2}$ was alternately cleaned by $\mathrm{RO}$ water and $\mathrm{EtOH}$ and collected by centrifugation at $10,000 \mathrm{rpm}$ twice. The collected $\mathrm{TiO}_{2}$ was then dried at $100{ }^{\circ} \mathrm{C}$ for 24 hours before use.

In the first step of membrane preparation, PSF pellets were dried at $80{ }^{\circ} \mathrm{C}$ for 24 hours to remove moisture. The dry/wet phase inversion method was used for membrane preparation in this research. Four types of membranes were prepared. They are pure PSF, $\mathrm{PSF} / \mathrm{TiO}_{2}, \mathrm{PSF} /\left(\mathrm{TiO}_{2}-\mathrm{TMMS}\right)$ and $\mathrm{PSF} /\left(\mathrm{TiO}_{2}-\mathrm{TEMS}\right)$ membranes. The $\mathrm{PSF} /\left(\mathrm{TiO}_{2}-\right.$ TMMS) and PSF/(TiO ${ }_{2}$-TEMS) ones were PSF membranes incorporated with $\mathrm{TiO}_{2}$ and further modified by TMMS and TEMS agent. The membrane designations before and after plasma treatment are shown in Table 2.

Table 2. Designation of the samples

\begin{tabular}{lll}
\hline Sample & Plasma Treated & Untreated \\
\hline $\mathrm{PSF}$ & $\mathrm{A} 1$ & $\mathrm{~B} 1$ \\
$\mathrm{PSF} / \mathrm{TiO}_{2}$ & $\mathrm{~A} 2$ & $\mathrm{~B} 2$ \\
$\mathrm{PSF} /\left(\mathrm{TiO}_{2}-\mathrm{TEMS}\right)$ & $\mathrm{A} 3$ & $\mathrm{~B} 3$ \\
$\mathrm{PSF} /\left(\mathrm{TiO}_{2}-\mathrm{TMMS}\right)$ & $\mathrm{A} 4$ & $\mathrm{~B} 4$ \\
\hline
\end{tabular}

During membrane preparations, PSF, DMAc, THF and $\mathrm{TiO}_{2}$ (or $\mathrm{TiO}_{2}-\mathrm{TMMS}_{\text {or }} \mathrm{TiO}_{2}$-TEMS) were blended at a weight ratio of 22.5:38.25:38.25:1.0, respectively, at $50-60{ }^{\circ} \mathrm{C}$ for 24 hours. The completely dissolved solution was then cast on a smooth and clear glass plate with a wetting thickness of about $150 \mu \mathrm{m}$. The cast membrane was freely placed in ambient air (evaporation time, ET) for 90 and $120 \mathrm{~s}$ before immersed in RO-water for $15 \mathrm{~min}$ followed by in $\mathrm{MeOH}$ solution for another 2.5 hours. Subsequently, the membrane was dried under ambient conditions for 24 hours. Finally, the membrane was dried in an electric oven at $70{ }^{\circ} \mathrm{C}$ for 12 hours before usage.

The optimized membrane surface was further modified by DC glow discharge plasma generated from Ar gas. The membrane sample was placed on the anode electrode as shown in Figure 1. The inter-electrode gap was controlled at about $3 \mathrm{~cm}$. Before Ar gas was fed into the plasma chamber, gas pressure in the chamber was controlled at $5.90 \times 10^{-2}$ mbar. Afterwards, Ar gas was fed into the chamber through a needle valve until the pressure reached $2.00 \times 10^{-1}$ mbar. The pressure was constant throughout the plasma treatment. Discharge power and treatment time were $20 \mathrm{~W}$ and $4 \mathrm{~min}$, respectively.

After plasma treatment, membrane hydrophilicity was determined by measurements of water contact angle (WCA) at different ageing times. The spread tendency of a liquid that drops on a smooth surface of a solid. To measure the WCA, the contact angle measuring instrument (Model OCA 15 EC, Data Physics Instruments GmbH, Germany) was used. Membrane samples for WCA measurements were cut into rectangular shape with a dimension of $3 \mathrm{~mm}$ in width and $10 \mathrm{~mm}$ in length. The membrane was fixed on a clear and smooth glass slide. Liquid was dropped on the 
membrane surface and the measured WCA was analyzed by using SCA software. The WCA was measured for at least three times per sample and the average was presented in Table 3. Fourier transform infra-red (FTIR) spectroscope was used to analyze the functional groups on the modified membrane surface. The distribution of $\mathrm{TiO}_{2}$ particles in the membrane matrix was analyzed through the micrograph of the scanning electron microscope (SEM) while the skin layer thickness was measured by SEM micrograph combined with the computer software, Carnoy versions $2.0^{\circledR}$. Atomic force microscope (AFM) was utilized to analyze the roughness of membrane surfaces. The separation properties of all resultant membranes were evaluated through gas permeation measurement.

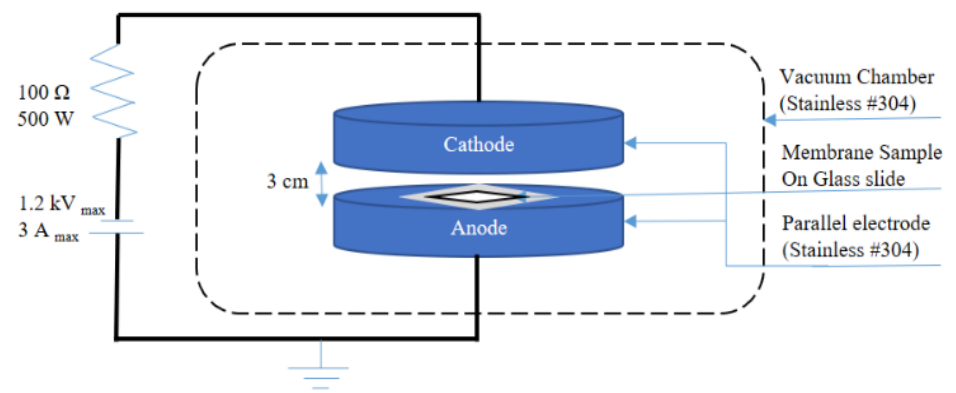

Figure 1. Schematic diagram of the membrane sample placed on the anode electrode in the DC plasma system used in this work.

Table 3. Water contact angle of membrane samples prepared at different conditions

\begin{tabular}{|c|c|c|}
\hline \multirow{2}{*}{ Samples } & \multicolumn{2}{|c|}{ Water contact angle $(\theta)$} \\
\hline & Evaporation Time (ET) $90 \mathrm{~s}$ & Evaporation Time (ET) $120 \mathrm{~s}$ \\
\hline B1 & $83.30 \pm 5.19$ & $83.80 \pm 6.22$ \\
\hline B2 & $92.36 \pm 2.09$ & $81.89 \pm 0.43$ \\
\hline B3 & $81.84 \pm 2.30$ & $89.86 \pm 1.82$ \\
\hline B4 & $72.95 \pm 1.83$ & $70.07 \pm 5.90$ \\
\hline
\end{tabular}

\section{Water contact angle}

\section{Results and Discussion}

As shown in Table 3, contact angles of membranes prepared at ET of $90 \mathrm{~s}$, it was found that WCA of B2 increased to $92.36^{\circ}$ whereas the WCA of B4 and B3 decreased to $72.95^{\circ}$ and $81.84^{\circ}$, respectively. For membranes prepared at ET of $120 \mathrm{~s}$, the highest WCA value was measured on the surface of B3 whereas the lowest WCA appeared on the surface of $\mathrm{B} 4$. WCA of $\mathrm{B} 4$ was $13^{\circ}$ lower than of the pure $\mathrm{B} 1$ membrane. This indicated that modified $\mathrm{TiO}_{2}$ by TMMS gave membranes with higher hydrophilic than by TEMS.

Table 4 shows the WCA of Ar-plasma treated membrane surfaces. It can be seen that WCA of PSF membranes that were plasma treated with a discharge power and exposure time of $20 \mathrm{~W}$ and $4 \mathrm{~min}$, respectively, decreased clearly. From Table 4, WCA of A4 membrane prepared at ET of 90 and $120 \mathrm{~s}$ decreased about $60^{\circ}$. The lowest WCA $(9.96$ $\pm 5.32^{\circ}$ ) appeared on the surface of A4 membrane prepared at ET of $120 \mathrm{~s}$. This phenomenon showed that TMMS affected the dispersion of $\mathrm{TiO}_{2}$ in the matrix of PSF membranes. Furthermore, the photocatalytic property of $\mathrm{TiO}_{2}$ in PSF membranes was stimulated by plasma radiation leading to an increase in hydrophilicity. TMMS showed an increase silane bonds on $\mathrm{TiO}_{2}$ surface which enable it to improve functional groups of organic compounds capture, as explained by Zhao et al. [16]. 
Table 4. Water contact angle of Ar-plasma treated (20 W, $4 \mathrm{~min})$ membranes

\begin{tabular}{|c|c|c|}
\hline \multirow{2}{*}{ Sample } & \multicolumn{2}{|c|}{ Contact angle $(\theta)$} \\
\hline & Evaporation Time (ET) $90 \mathrm{~s}$ & Evaporation Time (ET) $120 \mathrm{~s}$ \\
\hline A1 & $17.06 \pm 2.35$ & $15.34 \pm 1.35$ \\
\hline A2 & $17.36 \pm 2.51$ & $11.11 \pm 2.45$ \\
\hline A4 & $12.58 \pm 3.57$ & $9.96 \pm 2.32$ \\
\hline
\end{tabular}

When the surface of $\mathrm{TiO}_{2}$ was improved with $\mathrm{TMMS}, \mathrm{TiO}_{2}$ exhibited properties of organic material and was well dispersed in an organic membrane. Typically, $\mathrm{TiO}_{2}$ showed the photocatalytic properties after it was activated by plasma. These phenomena represent the increase of hydrophilic properties. Similar to Hashimato et al. [11] suggestion, $\mathrm{TiO}_{2}$ excited by ultraviolet (UV) light revealed hydrophilic properties. Besides, $\mathrm{TiO}_{2}$ can induce the dissociation of water without the use of external voltage. Therefore, $\mathrm{TiO}_{2}$ induced the surface of a membrane to be more hydrophilic. The glow discharge plasma consisted of several elements and a frequency range of UV. UV light encourages its photocatalytic properties. In this work, the permanency of hydrophilicity of plasma treated membrane was evaluated. We found that in the ageing time of 30 days, WCA of plasma treated membrane surface gradually retrieved to the WCA of pure and untreated PSF membrane. The WCA of pure and plasma treated membrane recovered faster when compared with A2 and A4 membranes. Importantly, the lowest recovery of WCA appeared on the surface of A4.

Figure 2 shows that the WCA of plasma treated PSF membranes was increased with ageing time. Using B1 as a reference, the WCA of A1 increased faster when compared with that of A2 and A4 membranes. However, WCA of $\mathrm{A} 1$ and became close to $\mathrm{B} 1$ membrane in the storage time of 25 days. The recovery rate of WCA in A2 was similar to the result obtained from A4 membrane. For A2 membranes prepared with ET of $120 \mathrm{~s}$, WCA increased to 56.25 $\pm 1.96^{\circ}$ after being stored at room temperature for 25 days, while the A4 at the same ageing time showed about $51.24 \pm 1.47^{\circ}$. It was clear that WCA at ageing time of 30 days of A4 recovered slower than that of A2 membranes. Additionally, for the membrane prepared with ET $90 \mathrm{~s}$, WCA of A2 and A4 membrane were about $70.33 \pm 1.24^{\circ}$ and $58.35 \pm 1.64^{\circ}$, respectively. It was confirmed that modified $\mathrm{TiO}_{2}$ can prolong the hydrophilicity of the plasma treated PSF membranes. Due to the fact that hydrophilicity of the membrane surface easily causes contamination by airborne smirch in ambient condition. This explained the temporary water-like property [6].

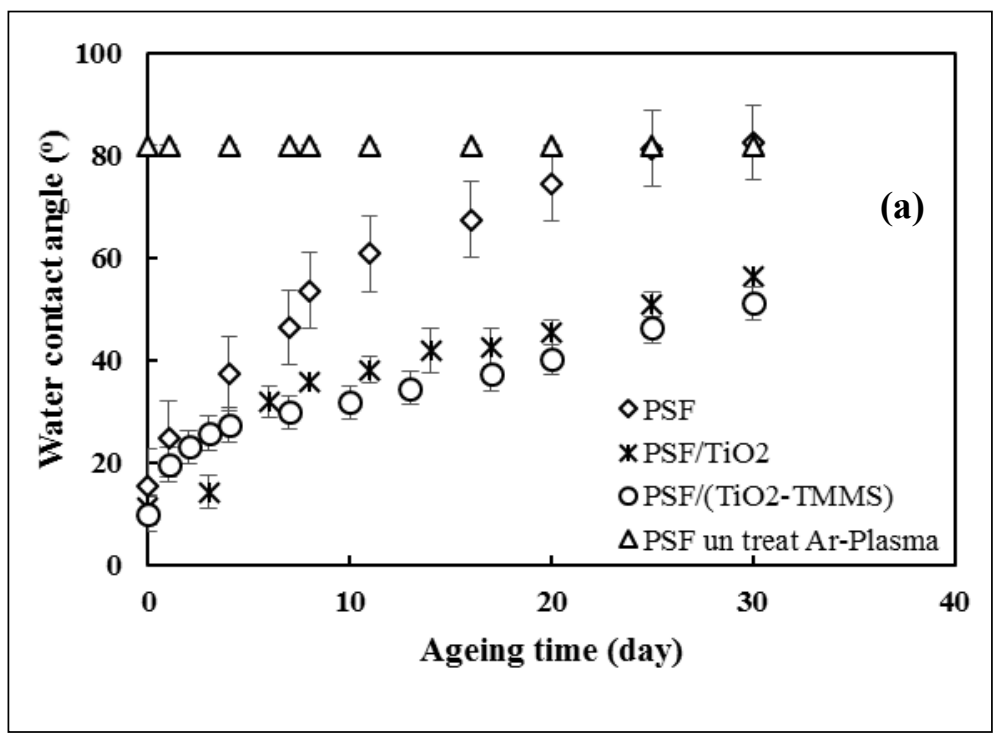




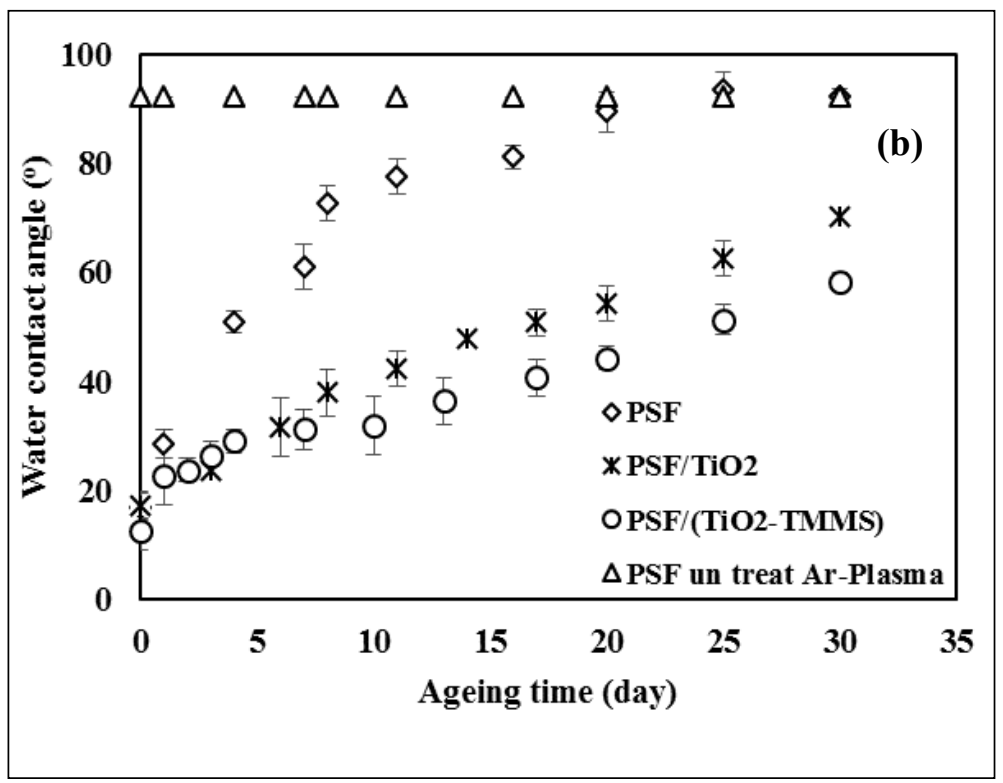

Figure 2. Variation of WCA with a storage time of 30 days of untreated and Ar-plasma treated membranes prepared at ET $120 \mathrm{~s}$ (a) and $90 \mathrm{~s}$ (b). PSF: A1, PSF/TiO2: A2, PSF/(TiO2-TMMS): A4 and PSF untreated Ar-Plasma: B1.

\section{Fourier transform infra-red spectroscopy}

Since PSF membranes are organic materials whereas $\mathrm{TiO}_{2}$ is an inorganic material, the agglomeration of $\mathrm{TiO}_{2}$ generally take place when it is blended in PSF membranes. To improve this problem, the modification of $\mathrm{TiO}_{2}$ surfaces by a silane coupling agent was conducted. The objective of this modification was to introduce the organic functional group on the surface of $\mathrm{TiO}_{2}$ nanoparticles. Introduction of organic groups on the surface of $\mathrm{TiO}_{2}$ affected the dispersion of them in the polymer matrix. Figure 3 shows the FTIR spectrum of B2 and B4 membranes. It is shown that the Ti-O-Si bonds [17] appeared in a wavenumber range of $910-960 \mathrm{~cm}^{-1}$. In the B4 system more Ti-O-Si bonds were created than in the B2 system. The number of Ti-O-Si bonds creations lead to an increase of the compatibility of the modified $\mathrm{TiO}_{2}$ with the matrix of PSF membranes.

\section{Scanning electron microscope results}

Figure 4 shows an SEM micrograph at a magnification of 5,000x of a membrane cross section and Figure 4(a) shows the thick and dense selective layer and a large number of pores in the sub-structure of B1. The agglomeration and dispersion of $\mathrm{TiO}_{2}$ particles in the membrane structure can be observed through the SEM micrograph. From Figure 4(a) and 4(b), the thicknesses of the skin layer membranes are 0.9 and $0.1 \mu \mathrm{m}$, respectively. $\mathrm{TiO}_{2}$ was dispersed less in the PSF matrix compared to the modified ones with TMMS. This shows the enhancement of Ti-OSi bonds in B4 membranes within $0.3 \mu \mathrm{m}$ membrane thickness. The selective or skin layer of both B2 and B4 was thinner than of the B1 membrane. Additionally, the wall of pore of B2 and B4 membranes were thicker than of the B1 membrane. The variation of skin layer thickness affected the gas permeation rate of prepared membranes. According to these reasons, the plasma treated membrane showed greater gas permeation rate in A4 membrane compared to that of $\mathrm{A} 1$ and $\mathrm{A} 2$ membranes. 


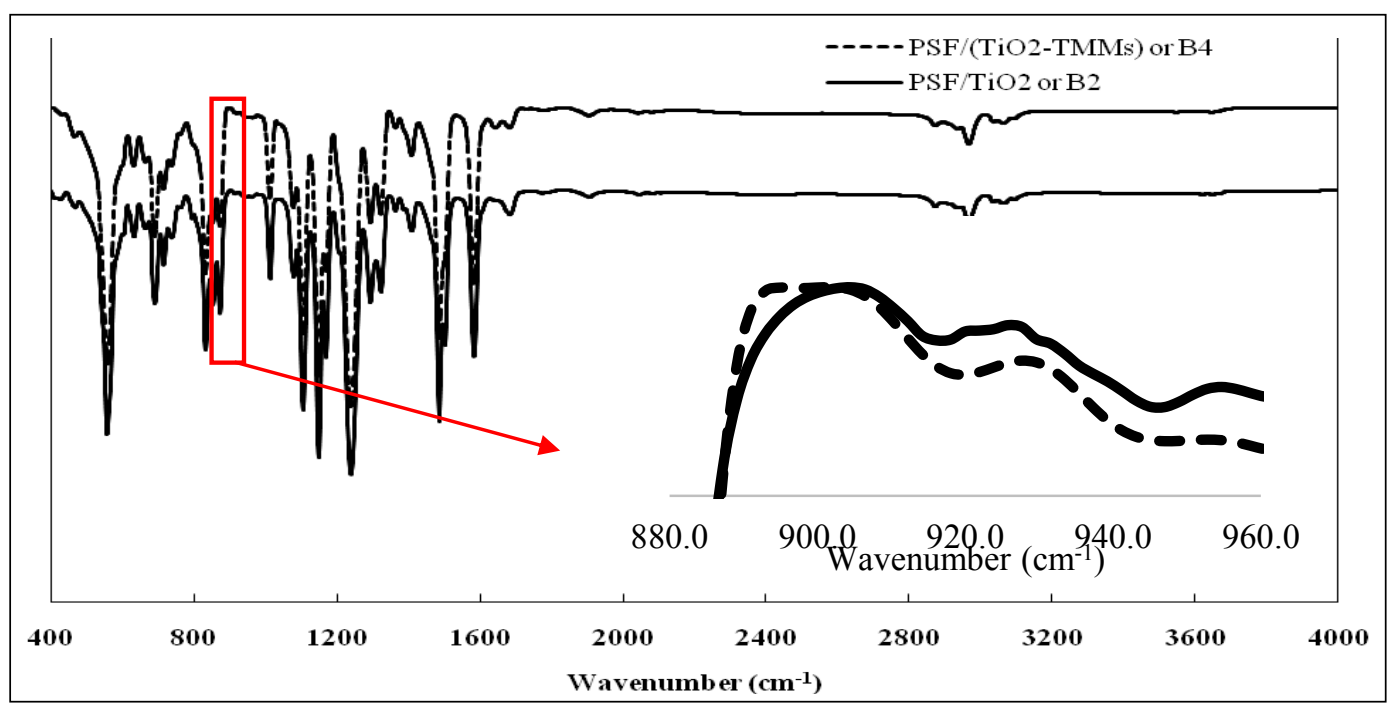

Figure 3. FTIR spectrum of $\mathrm{B} 2$ and $\mathrm{B} 4$ membranes.

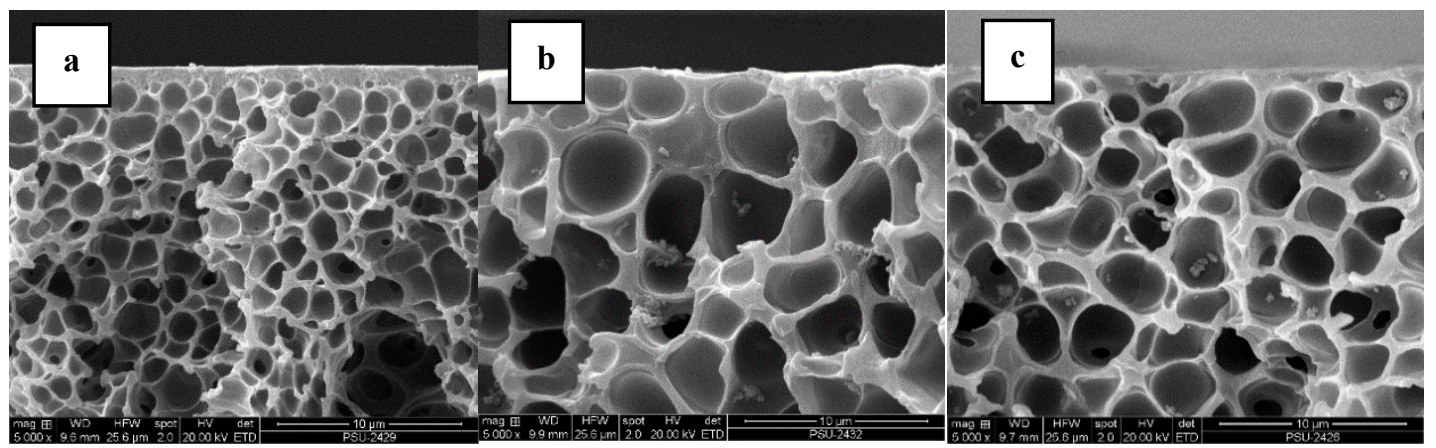

Figure 4. SEM micrographs (5,000x) of B1 (a), B2 (b) and B4 (c) membranes prepared with ET of $120 \mathrm{~s}$

\section{Atomic force microscope}

Figure 5(a) to (c) show the surface morphology of B1, B2, and A4 membranes. An area of $50 \times 50 \mu \mathrm{m}^{2}$ was scanned. It was shown that the highest roughness appeared on the surface of the B2 membrane prepared with ET of $120 \mathrm{~s}$, whereas for plasma treated $\mathrm{PSF} /\left(\mathrm{TiO}_{2}-\mathrm{TMMS}\right), \mathrm{A} 4$ membranes, the lowest roughness appeared when compared with $\mathrm{B} 2$ membranes. AFM results, when PSF was adulterated by $\mathrm{TiO}_{2}$ it creates more roughness on the membrane surface as shown in Figure $5 \mathrm{~b}$ (roughness at nanometer scale). After plasma treatment, the membrane surface was reduced in its roughness, as shown in Figure 5c. It should be emphasized that the smoother surface does not reflect more hydrophilicity upon the decrease nanoscale roughness, which then reduces the probability of the lotus effect occurrence. This finding is useful and can be explored further. 


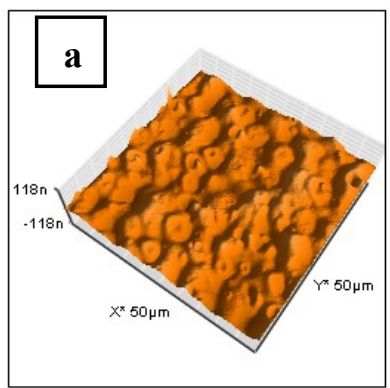

Rms $11.359 \mathrm{~nm}$

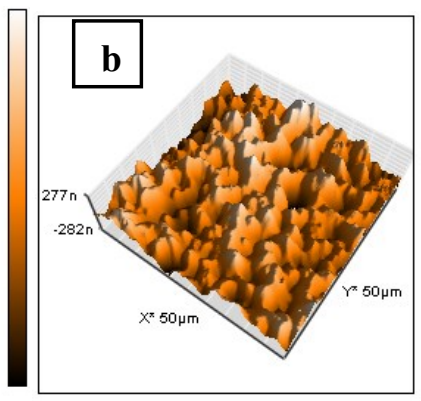

Rms $92.013 \mathrm{~nm}$

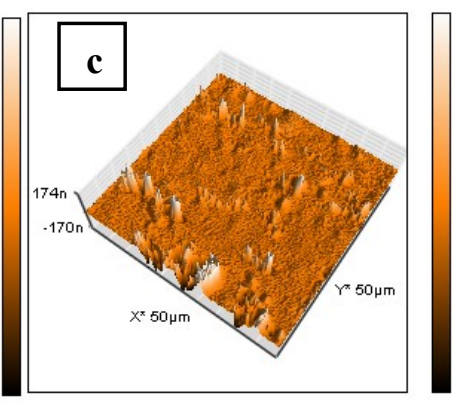

Rms $29.875 \mathrm{~nm}$

Figure 5. AFM micrographs of B1 (a), B2 (b), and A4(c) membranes after plasma treatment

\section{Gas permeation testing}

The maximum permeance of $\mathrm{CO}_{2}$ was about $80.81 \pm 0.09$ GPU measured with the A4 membrane, which was prepared with ET of $120 \mathrm{~s}$. This result corresponded to the aim of this study. The $\mathrm{CO}_{2}$ permeance of A4 membranes is higher than of $\mathrm{A} 1$ and $\mathrm{A} 2$ membranes prepared with the same ET. From Table 5, it can be seen that the $\mathrm{CO}_{2}$ permeance of A1 and A2 membranes were about $18.36 \pm 0.07$ and $17.46 \pm 0.05 \mathrm{GPU}$, respectively. Similarly, the permeance of $\mathrm{CH}_{4}$ increased from $3.29 \pm 0.05$ to $18.59 \pm 0.07 \mathrm{GPU}$ for A1 and A4 membranes, respectively. In addition to the gas permeance, the maximum $\mathrm{CO}_{2} / \mathrm{CH}_{4}$ selectivity was about $6.84 \pm 0.01$ for $\mathrm{A} 2$ membranes prepared with ET of $120 \mathrm{~s}$. It was shown that the selectivity of gas inversely varied with the gas permeance. Consequently, the minimum ideal $\mathrm{CO}_{2} / \mathrm{CH}_{4}$ selectivity of about $4.34 \pm 0.01$ determined for the $\mathrm{A} 4$ membranes because these membranes showed the maximum gas permeation. To enhance both the permeance and the selectivity of gases, further studies should be conducted with new aspects such as facilitated transport and refined mixed matrix membranes to be considered.

Table 5. Permeance (P/L) and ideal $\mathrm{CO}_{2} / \mathrm{CH}_{4}$ selectivity of plasma treated membranes (ET $120 \mathrm{~s}$ )

\begin{tabular}{|c|c|c|c|}
\hline \multirow[t]{2}{*}{ Sample, ET 120 s } & \multicolumn{2}{|c|}{ P/L (GPU) } & \multirow{2}{*}{$\begin{array}{c}\text { Selectivity of } \\
\mathrm{CO}_{2} / \mathrm{CH}_{4}\end{array}$} \\
\hline & $\mathrm{CO}_{2}$ & $\mathrm{CH}_{4}$ & \\
\hline A1 & $18.36( \pm 0.07)$ & $3.29( \pm 0.05)$ & $5.58( \pm 0.02)$ \\
\hline A2 & $17.46( \pm 0.05)$ & $2.55( \pm 0.02)$ & $6.84( \pm 0.01)$ \\
\hline A4 & $80.81( \pm 0.09)$ & $18.59( \pm 0.07)$ & $4.35( \pm 0.01)$ \\
\hline
\end{tabular}

\section{Conclusion}

In summary, preparation of flat sheet asymmetric PSF membranes by incorporation with the modified $\mathrm{TiO}_{2}$ at evaporation time (ET) of 90 and $120 \mathrm{~s}$ was conducted. $\mathrm{PSF} /\left(\mathrm{TiO}_{2}-\mathrm{TMMS}\right)$ membrane prepared with ET at $120 \mathrm{~s}$ showed better results for $\mathrm{CO}_{2}$ permeation by $340 \%$ and $363 \%$ compared with the $\mathrm{PSF}$ and $\mathrm{PSF} / \mathrm{TiO}_{2}$ membranes, respectively. Surface modification by DC Ar-plasma at indicated conditions showed improvement of membrane surface hydrophilicity. The maximum increase of the hydrophilic properties belonged to the plasma treated $\mathrm{PSF} /\left(\mathrm{TiO}_{2}\right.$-TMMS $)$ membrane preparing with ET at $120 \mathrm{~s}$. The plasma treatment decreased $\mathrm{WCA}$ by $85.78 \%$ in $\mathrm{PSF} /\left(\mathrm{TiO}_{2}\right.$-TMMS) membrane. Additionally, the permeance of the hydrophilic property created from Ar-plasma treatment for $\mathrm{PSF} /\left(\mathrm{TiO}_{2}-\mathrm{TMMS}\right)$ membranes was reported to improve. The hydrophilic property could sustain for over 30 days. The study of chemical change through the FTIR spectrum found an increase of Ti-O-Si bonds in the wavenumber range of 910-960 $\mathrm{cm}^{-1}$. This confirmed the bonding of $\mathrm{TiO}_{2}$ with TMMS coupling agent and lead to the enhancement of dispersion of modified $\mathrm{TiO}_{2}$ in the PSF membranes. The dispersion of $\mathrm{TiO}_{2}$ was also confirmed 
by SEM micrographs. This study also found that $\mathrm{TiO}_{2}$ modified with TMMS leading to the enhancement of their hydrophilicity, although a slight decrease in $\mathrm{CO}_{2} / \mathrm{CH}_{4}$ selectivity was evidenced.

\section{Acknowledgement}

Special thanks to Wanichapichart, P. and Durrast, H., Prince of Songkla University (PSU) for their kind editing. Financial support from the National Talented Scholarship in Science Project is also acknowledged. The authors would like to thank to the Membrane Science and Technology Research Center (MSTRC) and Physics Department, PSU for providing the infrastructure needed.

\section{References}

1. Yuenyao, C., Tirawanichakul, Y. and Chittrakarn, T. (2015). Asymmetric polysulfone gas separation membranes treated by low pressure DC glow discharge plasmas. Journal of Applied Polymer Science, 132(24): $42116-42126$.

2. Zhang, Y. and Liu, P. (2015). Polysulfone (PSF) composite membrane with micro-reaction locations (MRLs) made by doping sulfated $\mathrm{TiO}_{2}$ deposited on $\mathrm{SiO}_{2}$ nanotubes (STSNs) for cleaning waste water. Journal of Membrane Science, 493: 275 - 284.

3. Xueli, G., Haizeng, W., Jian, W., Xing, H. and Congjie, G. (2013). Surface-modified PSF UF membrane by $\mathrm{UV}$-assisted graft polymerization of capsaicin derivative moiety for fouling and bacterial resistance. Journal of Membrane Science, 445: 146 - 155.

4. Yang, Y., Zhang, H., Wang, P., Zheng, Q. and Li, J. (2007). The influence of nano-sized $\mathrm{TiO}_{2}$ fillers on the morphologies and properties of PSF UF membrane. Journal of Membrane Science, 288: 231 - 238.

5. Konruang, S., Sirijarukul, S., Wanichapichart, P., Yu, L. and Chittrakarn, T. (2015). Ultraviolet-ray treatment of polysulfone membranes on the $\mathrm{O}_{2} / \mathrm{N}_{2}$ and $\mathrm{CO}_{2} / \mathrm{CH}_{4}$ separation performance. Journal of Applied Polymer Science, 132(25): $42074-42082$.

6. Bae, Y.-S. and Lee, C.-H. (2005). Sorption kinetics of eight gases on a carbon molecular sieve at elevated pressure. Journal of Carbon, 43: 95 - 107.

7. Huang, S.-Y., Ganesan, P. and Popov, B. N. (2010). Electrocatalytic activity and stability of niobium-doped titanium oxide supported platinum catalyst for polymer electrolyte membrane fuel cells. Journal of Applied Catalysis B: Environmental, 96: $224-231$.

8. Albiter, E., Valenzuela, M. A., Alfaro, S., Valverde-Aguilar, G. and Martínez-Pallares, F. M. (2015). Photocatalytic deposition of $\mathrm{Ag}$ nanoparticles on $\mathrm{TiO}_{2}$ : Metal precursor effect on the structural and photoactivity properties. Journal of Saudi Chemical Society, 19: 563 - 573.

9. Djurišic, A. B., Leung, Y. H. and Ching Ng, A. M. (2014). Strategies for improving the efficiency of semiconductor metal oxide photocatalysis. Journal of Royal Society of Chemistry, 1: $400-410$.

10. Monllor-Satoca, D., Gómez, R., González-Hidalgo, M. and Salvador, P. (2007). The "Direct-Indirect" model: An alternative kinetic approach in heterogeneous photocatalysis based on the degree of interaction of dissolved pollutant species with the semiconductor surface. Journal of Catalysis Today, 129: $247-255$.

11. Hashimoto, K., Irie, H. and Fujishima, A. (2005). $\mathrm{TiO}_{2}$ photocatalysis: A historical overview and future prospects. Japanese Journal of Applied Physics, 44(12): 8269 - 8285.

12. Khatun, N., Rini, E. G., Shirage, P., Rajput, P., Jha, S. N. and Sen, S. (2016). Effect of lattice distortion on band gap decrement due to vanadium substitution in $\mathrm{TiO}_{2}$ nanoparticles. Journal of Materials Science in Semiconductor Processing, 50: 7 - 13 .

13. Liu, H., Lv, T. and Zhu, Z. (2016). Direct band gap narrowing of $\mathrm{TiO}_{2} / \mathrm{MoO}_{3}$ heterostructure composites for enhanced solar-driven photocatalytic activity. Journal of Solar Energy Materials \& Solar Cells, 153: $1-8$.

14. Madaeni, S. S., Badieh, M., Vatanpour, V. and Ghaemi, N. (2012). Effect of titanium dioxide nanoparticles on polydimethylsiloxane/polyethersulfone composite membranes for gas separation. Journal of Polymer Engineering and Science, 56: $2664-2674$.

15. Chen, Q. and Yakovlev, N. L. (2010). Adsorption and interaction of organic silanes on $\mathrm{TiO}_{2}$ nanoparticles. Journal of Applied Surface Science, 257: 1395 - 1400.

16. Zhao, J., Milanova, M., Marijn, M.C.G. and Dutschk, V. (2012). Surface modification of $\mathrm{TiO}_{2}$ nanoparticles with silane coupling agents. Journal of Colloids and Surfaces A, 413: $273-279$.

17. Li, Z., Hou, B., Xu, D., Sun, Y., Hu, W. and Deng, F. (2005). Comparative study of sol-gel-hydrothermal and sol-gel synthesis of titania-silica composite nanoparticles. Journal of Solid State Chemistry, 178: 1395 - 1405. 